\title{
O sociologické imaginaci ${ }^{1}$
}

\section{On the Sociological Imagination}

\section{Tomáš Kobes}

\begin{abstract}
This article discusses the controversy of the sociological imagination as it was developed by Charles Wright Mills and its relevance for the current epistemology of social science. His notion of the sociological imagination has several problems due to the unreflected general prejudice distinguishing between structure and subjectivity, which creates from sociology a kind of social metaphysics. As a result, social context is conceptualised as an unproblematic domain used for the rationalisation of an actor's behaviour and knowledge, and the sociological imagination gives the sociologist an absolute critical position which situates him paradoxically in the name of justice and freedom against humanity.
\end{abstract}

KEY WORDS sociological imagination, Mills, social metaphysics, social criticism

\section{Úvod}

Poté co Thomas Kuhn uveřejnil druhé vydání Struktury vědeckých revoluci (Kuhn 1970, česky 1997), vysloužil si ze strany sociálních vědců silnou kritiku pro nedůslednost ve vykazování souvislosti mezi paradigmatem a sociálním kontextem. Herminio Martins (1972) upozornil, že Kuhn v případě paradigmatické změny přehlíží externí sociální faktory. Podle Johna Urryho (1973) je paradigma vysvětlováno bez zjevného vztahu k sociálním a ekonomickým souvislostem. Lee Harvey (1982: 85) zdůraznil, že Kuhnův koncept selhává, protože se mu nedaří paradigma propojit se širším sociálním kontextem. Zřejmě nejlépe tento způsob kritiky vystihla Sheilla Jasanoffová (2012: 437), která Kuhnovu neschopnost vidět sociální podmíněnost vědy a její inklinaci k diskriminaci označila jako nedostatek sociologické imaginace.

Takto vedená kritika naznačuje, že sociologická imaginace jako prokazování souvislosti mezi určitým individuálním fenoménem, at’ již je to paradigma, určitá instituce či život jednotlivce, a sociálním kontextem, je pro sociologii či sociální vědu obecně důležitým epistemologickým předpokladem. Samotný Kuhn byl však vůči němu skeptický. Podle něj je tento přístup dogmatický a naivní, protože ne vše ve vztahu k formování vědeckého paradigmatu má sociologickou dimenzi (srov. Kuhn 1970: 137-138). Proč by tedy sociolog měl rozvíjet určitý, velmi specifický druh představivosti, u kterého se předpokládá, že se liší od ostatních vědních disciplín, a který však v očích nezasvěcených sociologii jako vědu spíše problematizuje a znevěrohodňuje už jen tím, že prokazování souvislosti mezi určitým fenoménem

Sociálni studia / Social Studies 1/2019. S. 147-162. ISSN 1214-813X.

1 Tato studie byla zpracována s podporou grantu Institucionální podpora na dlouhodobý koncepční rozvoj výzkumné organizace - KSS FF ZČU v Plzni. 
a širším sociálním kontextem svádí k perspektivě, v níž jsou sociální struktury předpokládány jako mnohem reálnější entity než daný jev? Odkud se bere tato tendence, v níž je sociální kontext pojímán jako neproblematická oblast využívaná badatelem pro racionalizaci jednání a myšlení určitých aktérů, která ho však pasuje do role absolutního měřítka všeho a všech a ve svém důsledku staví sociální vědu nejen proti vědám ostatním, ale především proti člověku? Pokusím se tento postoj blíže vysvětlit.

I.

Termín „sociologická imaginace“ do sociologického pojmosloví zavedl Charles Wright Mills ve stejnojmenné knize vydané poprvé v roce 1959 (česky poprvé v roce 1968 a pak v roce 2002). Byla uveřejněna po Millsově úspěšné „trilogii“ řazené dnes již mezi klasické sociologické práce. V The New Men of Power: America's Labor Leaders (1948) se soustředil na význam odborového hnutí, aby na základě americké zkušenosti ze 40. let 20. století poukázal, jak došlo ke zhroucení jeho původního programu. Bílé límečky (v anglickém originálu White Collar) (1951) nastolují téma moci v kontextu byrokracie, vnášející tak vhled nejen do chodu byrokratického systému Spojených států, ale také zájmu americké střední třídy. V Mocenské elitě (anglicky The Power Ellite) (1956) svoji pozornost zaměřil na výkon moci mezi politickými, ekonomickými a vojenskými elitami americké společnosti.

Sociologická imaginace je však jiná. Mills se v ní obrací k sociální vědě. Je budována jako kritika aktuální podoby sociologie či obecněji sociálních věd se záměrem vytyčit jejich nový vědecký program především ve vztahu k veřejnosti. Podle Millse dvě velké ideologie socialismu a liberalismu selhaly, protože se zrodily jako teorie společností, které v Millsově věku již neexistovaly. V nadcházejícím post-moderní věku je příliš zřejmé, že prohlubující se racionalita není př́liš dobrým předpokladem rostoucí svobody. Žijeme ve věku zhroucení souladu rozumu a svobody, které však není ani jako problém uznáno a formulováno (srov. Mills 2008: 180-183). To je Millsův ústřední bod, od kterého odvíjí svoji kritiku.

Nejprve se ohrazuje vůči tzv. velké teorii reprezentované Talcottem Parsonsem a abstraktním empirickým výzkumům prosazovaným zejména Paulem Lazarsfeldem. Podle Millse základní problém „velké teorie“ je její príilišná obecnost, kterou je obtížné vztáhnout k reálné praxi. Výsledkem je fetišizace pojmů, ze kterých se stávají jen nezbytné sociologické floskule, které nevedou k vymezení a postižení aktuálních sociálních problémů, nebo naopak jejich aplikace na konkrétní sociální fenomén vede k banálním zjištěním (ibid.: 40-41).

Abstraktní empiricismus oproti tomu v Millsových očích vytrvale směšuje předmět výzkumu s navrhovanými metodami tohoto výzkumu. Zde již nejde podle Millse o teorii, zato je abstraktní empiricismus pro dosažení výzkumného záměru charakteristický vytvářením rozsáhlého byrokratického aparátu. Při tom se opírá o propracovanou legitimizační strategii, v níž zdůrazňuje, že je v sociálních vědách jediným reprezentantem skutečných vědců a jeho epistemologie koresponduje $\mathrm{s}$ vědeckým programem prŕrodních věd, který je však redukován na postup typický pro demografii či ekonomii, v němž jde především o postižení statistického významu. Výsledkem je sofistikovaný rituál, který byl postupně komercializován, a požadavek vědy byl odsunut na okraj (srov. ibid.: 63-70; 81). 
Mills se snaží nedostatečnost „,velké teorie“ a abstraktního empiricismu nahradit novým vědeckým programem sociálních věd a vymezit jejich úlohu ve vztahu k veřejnosti. Výchozím předpokladem je sjednocení sociální vědy. Nikoli však v jednoduché fúzi pod nějaký nový zastřešující termín, ale $\mathrm{v}$ obeznámenosti s koncepcemi a metodami ostatních disciplín, v jejímž rámci by specializace vyplývala ze soustředění se na ,aktuální“, a tedy „významný problém“, nikoli z pouhého dodržování akademických hranic (ibid.: 154). Je to tento „aktuální - významný problém“, kolem kterého chce Mills budovat svůj nový vědecký program sociálních věd. Neznamená to však, že by šlo o problém, který by měl politický, praktický či ekonomický význam, ale o problém, který je významný vzhledem k sociální struktuře (srov. ibid.: 82). Úkolem sociologa či sociálního vědce je naučit se rozpoznávat sociální struktury v jejich historické dimenzi se záměrem vztahovat biografie jednotlivců k existujícím strukturám. Takový program dostává do zorného pole člověka jako lidskou bytost v dimenzích svobody a rozumu, protože navzdory obecným proklamacím o osvícenosti moderní doby lidé podle Millse stále žijí v zajetí pověr, mýtů a bludů (ibid.: 171 a 182).

Podstatným předpokladem k postižení takto vystavěného problému je pro Millse cosi, co označil jako sociologickou imaginaci. Průběh dějin je podle něj mnohem rychlejší než schopnost orientovat se v nich v souladu s všeobecně uznávanými hodnotami vedoucími k tomu, že lidé nejsou způsobilí k pochopení významu epochy, v níž žijí. Aby toho byli schopni, nepotřebují tito dezorientovaní usměvaví roboti, jak Mills rád pojmenovává své současníky, pouze informace, které vzhledem k jejich narůstajícímu objemu nejsou schopni vyhodnocovat, ale zvláštní duševní schopnost, která by jim umožnila správně dané informace využít a pochopit, k čemu dochází ve světě a co se odehrává v nich samých (ibid.: 8-9).

Sociologická imaginace umožňuje těm, kdo ji mají, pochopit širší historickou scénu v jejím významu pro vnitřní život a pro vnější životní dráhu různých jednotlivců. Umožňuje jim pochopit, jak jednotlivci ve změti svých každodenních zkušeností získávají mnohdy falešné vědomí o svém společenském postavení. V této změti je nutno odkrývat strukturu moderní společnosti, v níž se formuje psychologie mužů a žen. (ibid.: 9)

Pro Millse je v jeho novém vědeckém programu podstatné naučit se odhalovat souvislosti v jejich strukturálních rysech ovlivňujících subjektivitu jednotlivců a podílejících se na jejich falešném vědomím. Sociolog by se měl stát profesionálem v odhalování těchto vzájemných vztahů struktury a vědomí a zároveň propagátorem této zvláštní schopnosti či dovednosti tak, aby ji ovládli i lidé, kteří nejsou primárně sociálními vědci. Sociální imaginace jako nový vědecký program je tak rovněž v Millsově pojetí morálním údělem postulujícím společenskou odpovědnost sociální vědy.

II.

Sociologie má v kritické reflexivitě svého oboru jistou tradici. Před Millsem Robert Lynd v roce 1939 zveřejnil první systematičtější kritiku sociální vědy, v níž, podobně jako později Mills, sociologii obvinil z neschopnosti formulovat závažné sociální problémy a navrhovat adekvátní způsoby řešení, které by nehájily pouze privátní zájem univerzit a jejich donorů. 
Tato nemohoucnost však nevyplývá jednoduše z toho, že by sociální vědci disponovali špatnými daty, ale protože je sociální věda realizována především univerzitními vědci, kteří jsou najímáni privátním sektorem. V důsledku tohoto stavu se ustálil určitý status quo, díky němuž je sociální vědec chycen do pasti soupeřících požadavků privátního a obecného zájmu. Univerzitní administrátoři, dnes bychom řekli spíše univerzitní management, se soustředí na prosperitu univerzity, která však není synonymem pro prosperující společnost. Výsledkem je definování role univerzit, se kterým jde ruku v ruce vymezení sociální vědy, nikoli jako instituce, která by měla přispívat k řešení aktuálních problémů, ale poskytovat takové vzdělání, které pomůže absolventovi reagovat na různé životní problémy. Krize sociální vědy vyplývá z tohoto dilematu. Jakékoli rozhodnutí na úrovni veřejné či univerzitní politiky se koná bez sociální vědy (srov. Lynd 1939/1970: 1-9).

Millsovu Sociologickou imaginaci lze číst jako pokračování Lyndem vytyčené kritiky. Reflektuje nejen to, že sociologie přehlíží závažný společenský problém, ale rovněž upozorňuje na epistemologické důsledky dvou stylů rozprostírajících se mezi abstraktní teorií a důsledným empiricismem. Stejně tak upozorňuje na prohlubující se byrokratizaci, technokratizaci a komercializaci sociologických výzkumů, a jak se tato praxe promítá do kriteriálních nároků „být vědecký“ především v akademickém prostředí. Lze říci, že svými úvahami vytvořil možnost pro ucelený reflexivní obrat v sociologii dopracovaný především Pierrem Bourdieuem (2003) nebo Alvinem Gouldnerem (1970, 1973), který začal od 70. let 20. století otevřeně mluvit o krizi (západní) sociologie.

Zároveň jde o pokus navrátit sociální vědy blíže k člověku, který vyvrcholil programem veřejné sociologie Michaela Burawoye proměněné ve vizi akční či spontánní sociologie (Burawoy 2005, 2008). Zvláště Burawoy oceňuje význam Millsovy sociologické imaginace a poukazuje, jak se podílí na formování sociologické agendy, která do centra pozornosti staví moc a sociální nerovnosti ve vztahu k rase, genderu či sexualitě. Díky ní mohou sociologové podle Burawoye demonstrovat, že individuální zkušenost není produktem jejich osobitosti, ale existujících sociálních sil. Je to především tato rovina, která činí sociologickou imaginaci pro mnohé sociology zajímavou a činí z ní principiální přednost, která je v různých obměnách zdůrazňována $\mathrm{v}$ mnoha úvodech do sociologie pohybující se mezi výzkumnou strategií a určitou schopností či kvalitou mysli.

Např́klad Henry L. Tischler sociologickou imaginaci představuje jako proces zkoumání vzorců chování a jejich souvislostí mezi nimi a tím, že zaznamenáváme podobnosti v jednání jednotlivců a hledáme síly, které ho formují (Tischler 2007: 6). Ken Browne upozorňuje, že sociologická imaginace je studium běžných denních rutin z neobvyklého úhlu pohledu. V tomto smyslu se sociologové ptají, zda jsou věci ve skutečnosti tak, jak napovídá zdravý rozum (Browne 2005: 2). Anthony Giddens naopak sociologickou imaginaci spojuje se schopností odmyslet si rutiny každodenního života, abychom se na něj dokázali podívat novým způsobem. Takto rozvíjený imaginativní přístup sociologovi jako vědci umožní ukázat nejen to, co se děje, ale i to, co by se mohlo stát (Giddens 2005: 18-19). Podobně Kerry Ferrisová a Jill Steinová sociologickou imaginaci charakterizují jako kvalitu mysli, která umožňuje porozumět vztahům mezi životní situací jednotlivce a tím, co se odehrává v sociální rovině (Ferris, Stein 2010: 16).

Mnozí však Millsovi vyčítají, že navrátil do sociologie klasická témata (viz Binns 1977: 123; Denzin 1989, 1990; Rosenberg 1994; Seidman 2013: 103). Především Norman 
Denzin $(1989,1990)$ je vůči Millsovi velmi kritický. Vytýká mu, že při kritice moderní teorie odkazuje k moderním ideálům, jako jsou rozum, svoboda, demokracie, pozitivní vědění, a vzhledem k nim nabízí velmi slabý epistemologický program spočívající ve vizi sociologické imaginace. Podle Denzina je Sociologická imaginace pokryteckým a manipulativním textem, který vznikl jako rozhořčení nad pochybným stavem sociologie. Zatímco všichni jsou situování v sérii životních pastí, Mills se pod vlivem své imaginace situuje do nikým a ničím nepodmíněné pozice. Je objektivním pozorovatelem mimo historii či sociologii snažícím se přeměnit sociologickou imaginaci v sílu, která může změnit historii. Proč se však navzdory tak odmítavé kritice stala sociologická imaginace tak podmanivou a ve svém důsledku především v úvodech do sociologie tak široce propagovanou nutnou dispozicí pro výkon sociologie jako vědy?

III.

Podle Jana Balona (2009) je tento ambivalentní odkaz Millsovy Sociologické imaginace způsoben především tím, že se z ní od jejího prvního vydání stala sociologická klasika, která je otevřená mnohočetnému způsobu čtení, a je jí tak možné rozumět téměř jakkoli. Pro jedny se stala důležitým kritickým nástrojem teoretické a metodologické omezenosti sociologie jako vědy. Pro druhé je zdrojem různých sociologických klišé vyplývajících především z přehnaného důrazu na její přelomovost. Stejně ji lze číst jako narcistický autoportrét nebo jako uprímnou starost o svět (Balon 2009: 1069).

Přesto by nemělo $\mathrm{v}$ těchto často protikladných interpretacích zaniknout, že Mills v kritice „velké teorie“ velice dobře pojmenoval základní úskalí upjatého důrazu na teorie v sociálněvědním výzkumu. Především platí argument týkající se pojmového fetišismu, který není nutně typický jen pro Parsonsův strukturální funkcionalismus. Podobným osudem je poznamenán i sociální konstruktivismus nebo diskurzivní přístup. „Sociální konstrukce“ je v současnosti nadužívaný termín, stejně jako „gender“ nebo „diskurz“ (srov. např. Daly 2005; Fowler 1996; Hacking 1999; Hanish et al. 2013; Latour 2002). Dnes již však nejde o rizika vyplývající z existence nekritického využívání jedné teorie, ale o existenci teoretické plurality vedoucí $\mathrm{k}$ charakteristikám sociální vědy jako multiparadigmatické disciplíny. Již nejde jednoduše o přeměnu teorie $\mathrm{v}$ ideologii ani o pohled na teorii jako jednu z mnoha ideologických nástrojů (srov. Beck 2007; Feyerabend 1993; Sunderlin 2003), ale o úskalí vyplývající z prosté možnosti teoretického výběru.

Jaroslav Šotola (2018) ve svém nedávném diskusním příspěvku zdůraznil, že ve velkém množství (teoretických) perspektiv o člověku a společnosti spočívá hodnota a význam pro demokratickou společnost. Může však mít věda ve svém zorném poli takto jednoduše demokratičnost společnosti? Nezpochybňuje se tím heuristická hodnota sociální vědy a nedegraduje ji na politiku se všemi negativními důsledky, které jsou s ní spojeny? Dovolím si tvrdit, že tato perspektiva teoretické plurality přehližź jednou podstatnou rovinu. Teorie nevznikají kvůli možnosti svobodného či libovolného výběru nebo kvůli demokracii, ale ve snaze vysvětlit vzhledem k existující teorii neobvyklý jev. Rovněž se přehlíží, že existující teorie jsou ve svých východiscích nikoli komplementární, ale velice často nesouměřitelné, a že tato nesouměřitelnost postuluje problém, který teoretické fúze přehlížejí, nebo dokonce popírají. 
Například Dušan Lužný již jistou dobu usiluje o teoretické sjednocení konstruktivistického a kognitivního přístupu (srov. Lužný 2014; Lužný a Váně 2017). Stejně dlouho ale přehlíží jeden podstatný rys. Kognitivní přístup, stejně jako konstruktivismus, shledává jazyk jako výchozí bod svého zájmu, a dříve nebo později snaha o jejich teoretickou fúzi narazí na problém vyplývající z otázky, zda jsme do jazyka socializováni, nebo k němu máme přirozené schopnosti, které se spolupodílejí na organizaci sociálních vztahů.

Rovněž platí některé Millsovy námitky vůči abstraktnímu empirismu. Kvantitativně orientované výzkumy se stále soustredí na prokázání statistické významnosti ve vztahu k tradičním sociologickým proměnným bez zjevného vztahu k logice zkoumané sociální praxe. Když se Dana Hamplová (2011) snaží vysvětlit, proč jsou ženy zbožnější než muži, hledá souvislost mezi zaměstnaností, ekonomickými postavením, faktorem sociální deprivace a socializace s předpokladem, že každá z těchto oblastí má potenciál vysvětlit důvody tohoto rozdílu. Redukuje zbožnost na tyto proměnné s očekáváním, že ekonomická situace či způsob socializace určitého jednotlivce se promítne do jeho religiozity. Text je zakončen následujícím zjištěním:

Závěr, že žádná z uvedených teorií nevysvětluje rozdíly v religiozitě českých mužů a žen, by však byl předčasný. Naše výsledky jsou nepochybně ovlivněny daty i proměnnými, které používáme a které nemusejí vždy ideálně vystihovat daný koncept. Nepochybným omezením našich analýz rovněž je, že nemáme $\mathrm{k}$ dispozici longitudinální data a respondenty pozorujeme pouze $\mathrm{v}$ jednom časovém bodě, a nemůžeme tak vždy jasně určit, co je př́ičinou a co důsledkem. Musíme proto nakonec konstatovat, že naše analýzy sice nepotvrdily platnost žádné ze standardních sociologických teorií vysvětlujících rozdíly v religiozitě mužů a žen, ale náš závěr nemůže být konečný. (Hamplová 2011: 320)

Nedostatek informací v tomto případě vystupuje jako principiální přednost, v níž jde především o demonstraci metody. Měření př́rodních věd, které je ve vztahu k velmi složitým a sofistikovaným měřicím př́strojům, jsou nahrazována technikami dotazování doprovázenými mnohdy rozsáhlým administrativním aparátem, v jehož rámci jsou empirická data zpracovávána přesnými matematickými postupy, kde však interpretace výsledků neaspiruje na vysvětlení, ale je odhadem, zda existence určitého jevu má vzhledem ke sledovaným proměnným souvislost či nikoli. Informací o současném stavu společnosti je v takových textech poskrovnu.

Stále také platí Millsova výtka týkající se komercializace empirického výzkumu. Jeho postupy jsou dnes integrální součástí jak výzkumu veřejného mínění, tak marketingu, kde je kladen důraz na praktickou využitelnost ve výzkumu prověřených metod. Sociolog či sociální vědec poskytuje nástroj a dovednost nikoli ve vztahu k problému, ale ve jménu úspěchu produktu či úspěchu příslušné agentury v přesnosti odhadu veřejného mínění (např́íklad volebních výsledků). Metoda a výzkum jsou důležitými marketingovými nástroji, aniž přinášejí nové zásadní poznatky o současné společnosti.

Přes některé stále platné postřehy se však Mills ve své vizi nového programu sociální vědy mýlil. Sjednocení sociální vědy je iluzorní a nikdy nenastalo. Rozdíly mezi jednotlivými sociálněvědními disciplínami se prohlubují a interdisciplinarita propagovaná ještě v 90 . letech 20. století se jeví jako neuskutečnitelná (srov. např. Katz 2001). Mita Giacomini (2004) upozorňuje, že z interdisciplinárního snu se stala spíše noční můra. Jednotlivé disciplíny tvoří oddělené 
ostrovy znalostí. Izolovaní odborníci nemohou rozpoznat relevantní námitky ostatních specialistů, protože jsou uvězněni ve svém vlastním žargonu, a diskuse mezi nimi více připomíná zmatení jazyků. Celý problém je umocněn přenesením interdisciplinárního ideálu do spolupráce mezi komerčním a akademickým sektorem, $v$ níž je interdisciplinarita koncipována jako nejvyšší veřejný zájem. Noční můra se pak prohlubuje $\mathrm{v}$ konfliktu, $\mathrm{v}$ jehož rámci je tento obecně deklarovaný veřejný zájem redukován na zájem průmyslu či vládních politik neustále definující parametry, které podle Giacomini z vědcu činí spiše oportunisty než seriózní badatele.

Toto úskalí částečně vyplývá z tendence, v níž jsou př́islušné předměty zájmu spíše vytrhávány z jejich souvislostí již jen na základě tendence je vymezit jako distinktivní oblasti, které je staví do nesouměřitelné pozice (srov. např. Latour 2003, 2005). To je jeden ze základních zdrojů vědeckých válek nejen mezi přírodními a sociálními vědami, ale mezi sociálními vědami navzájem, které jsou prohlubovány především otázkou společenské významnosti a potřebnosti již jen v kontextu způsobů financování vysokých škol a výzkumu. Otázkou je, zda si z tohoto pohledu lze dovolit nemít erudované techniky či biology? Je však skutečně žádoucí mít erudované techniky či biology, kteří budou zpochybňovat holokaust nebo budou dlouhodobě podněcovat k nenávisti či omezování práv a svobod, at' již jsou vymezeny jakkoli? Pravděpodobně nikoli. Můžeme si však z tohoto hlediska dovolit sociální vědce, kteř́ nemají ponětí o aktuálních poznatcích přírodních věd? A můžeme tolerovat sociální vědce se zjevným rasismem? Jakou roli tedy mají vzhledem $\mathrm{k}$ takovému požadavku $\mathrm{v}$ budoucnu sehrávat sociální vědy? Mají být budovány jako základní emancipační nástroj směřovaný proti útlaku ve všech jeho možných podobách, opírající se o sociologickou imaginaci jako nezbytný předpoklad? Zdá se, že Millsův požadavek sociální vědy ve vztahu k problému svobody a rozumu stále platí. Domnívám se však, že jeho základní chyba spočívá v samotné sociologické imaginaci, která se snaží zprostředkovat vztah mezi vnější realitou opisovanou sociálním kontextem, sociální strukturou, silami, tlaky, či diskurzy a subjektivitou konkrétního jednotlivce. Zřejmě nejucelenější katalog těchto nadindividuálních entit ovlivňujících život individuí se podařilo sestavit Joan Ferranteové.

Sociální síly jsou cokoliv lidského nebo jinak utvářeného, které ovlivňují nebo vytvářejí nátlak na lidi, aby interagovali, jednali nebo mysleli určitými způsoby. Sociální síly lidé mohou přijímat, být jimi usměrňováni, přehlíženi nebo jim vzdorovat. Mezi př́klady sociálních sil, kterými se sociologové zabývají, patř́ globalizace, rasová klasifikace, technologie, symbolika a instituce. (Ferrante 2010: 5) ${ }^{2}$

\section{IV.}

Tato tendence odpovídá obecným definicím imaginace, vymezující ji jako schopnost představit si to, co není prítomno v lidských smyslech. Imaginace je zde způsobem zprostředkování mezi tím, co je považováno vzhledem k člověku za vnější realitu, a lidským nitrem

2 Social forces are anything human or otherwise created that influence, pressure, or push people to interact, behave, or think in specified ways. People can embrace social forces, be swept along, be bypassed by them, or challenge them. Examples of the many social forces sociologists study include globalization, racial classification, technology, symbolic meanings, and institutions (Ferrante 2010: 5). 
především ve vztahu k internalizovaným obsahům lidského vědomí, které nemusí nutně odpovídat skutečnosti (srov. Perdue 2003).

V tomto smyslu je pro pochopení Millsovy sociologické imaginace užitečné obrátit pozornost k jeho raným teoretickým textům (1939, 1940a, 1940b), dokumentujícím způsob posunu od subjektivity k sociální struktuře, či obecněji od imanence k transcendenci činící ze sociologie spíše sociální metafyziku. Prvotním záměrem těchto texti̊ bylo samozřejmě něco jiného. Millsovi šlo primárně o vypracování sociální teorie vědomí, v níž kombinoval sociologii vědění Karla Mannheima a pragmatismus Johna Deweye. Podle Neila Grosse Mills od Deweye převzal perspektivu, podle níž by lidé žijící v moderní demokratické společnosti měli být obeznámeni s důsledky veřejných politik tak, aby je byli schopni akceptovat nebo zamítnout. Mills ji transformoval do sociologické imaginace, díky níž by byli lidé schopni spojit své osobní potíže s veřejnými problémy a způsoby organizace společnosti (Gross 2007: 205).

V Mannheimově sociologii vědění naopak spatřoval nástroj pro historickou rekonstrukci myšlení, včetně zohlednění jejích východisek pro reflexi sociologické teorie a metodologie. Podstatnou byla pro Millse především snaha zprostředkovat formování a změny myšlení či určité doktríny ve vztahu k sociálním strukturám, třídám a technologickým změnám tak, aby byl schopen vytvořit takovou teorii vědomí, která by zohlednila (vnější) sociální procesy podstatné pro (vnitřní) mentální operace (srov. Mills 1939: 670-671). Podle Millse aktér nehraje aktivní roli v širších institucionálních rámcích či sociálních vrstvách a neutváŕí svým jednáním obecný vzorec určitého zvyku, který by vedl k vytvoření detektoru určitých problémů. Přičemž sociální problém je zde vymezen jako důsledek způsobu organizace sociálního jednání, který preferuje jen určité hodnoty (srov. ibid.: 675).

Tento vztah mezi vnějším způsobem organizace a určitým způsobem myšlení Mills popisuje jako socio-psychologický mechanismus, který je umožněn jazykem, jehož slovník nelze koncipovat pouze jako řadu slov, ale jsou v něm obsaženy sociální, institucionální a politické koordináty. Skrze ně pak můžeme lokalizovat jakéhokoli aktéra. Studiem jeho slovní zásoby lze detekovat implicitní hodnotový systém a kolektivní vzorce, které tvoří její pozadí. Podstatné je, že podle Millse žádný aktér není schopen rozeznat významovou arbitrárnost ani způsoby, jak jsou jednotlivé významy předem dány jako sociální výtvory (ibid.: 677-678). Zdroj způsobu mluvy, jednání, myšlení vyplývá ze situovanosti daného aktéra, která pro něj není zjevná.

V rámci perspektivy, které je brána v potaz, verbalizovaný motiv není využíán jako index něčeho individuálního, ale jako východisko pro představu typického slovníku motivů situovaného jednání. (...). Připsání motivů může být kontrolováno vztahováním k jejich typickým konstelacím, které jsou pozorovány jako sociálně provázané s třídami situovaných jednání. Některé z těchto "reálných" motivů, které byly přisouzeny aktérům, jim dokonce nejsou známy. (Mills 1940a: 909-910)

3 Within the perspective under consideration, the verbalized motive is not used as an index of something in the individual but as a basis of inference for a typical vocabulary of motives of a situated action. (...) Imputation of motives may be controlled by reference to the typical constellation of motives which are observed to be societally linked with classes of situated actions. Some of the "real" motives that have been imputed to actors were not even known to them (Mills 1940a: 909-910). 
V tomto smyslu motivy sociálního jednání variují nejen podle historické epochy, ale také podle sociálních struktur, a Mills se zasazuje, aby jednání a jazyk nebyly vysvětlovány jako externí manifestace subjektivity, ale jako důsledek sociální situovanosti určitého subjektu, která vytváŕí rámec daných motivů jednání a jazyka (ibid.: 913). Tento princip lze pak analogicky vztáhnout i na různé vědecké modely a strategie.

Podle Millse veškeré kategorie různých diskurzů závisejí na jejich sociálních situacích či kulturních determinantech. Z toho vyvozuje, že kategorie reprezentují především sociální teorii percepce. Jednotlivé koncepty různých epistemologií ovlivňují to, co je možné vidět a zaznamenat. Složka pozorování jakéhokoli verifikačního modelu je ovlivněna jazykovými koncepty daného mluvčího a sociologie vědění se tak podle Millse vyhýbá absolutnímu měřítku, protože postihuje jen podmínky, za kterých jsou jisté jevy pravdivé (Mills 1940b: 318-324).

Tento bod je klíčový pro pochopení, jak si Mills v relativistickém postoji vytváří absolutní měřítko typické pro svou sociální imaginaci. Věda v ní ztrácí výlučné postavení a je vymezena jako sociální produkt, stavěný na roveň technikám common sensu, který lze zredukovat na problém rozdílu mezi chováním ovlivněným existujícím sociálním rádem a tím, co je řečeno aktéry v odlišných kontextech.

Nyní se sociolog vědění explicitně zaobírá faktickým výzkumem verbálních komponent jednání, „zdravým rozumem“, např. artikulací různých kultur. V tomto terénu je jedním z jeho problémů odkrytí rozporů mezi zjevnými systémy chování a co je řečeno aktéry v odlišných kulturních kontextech. (Mills 1940b: 329) ${ }^{4}$

Diskrepance mezi jednáním a myšlením nejenže umožní sociálním vědám zlepšovat své techniky dotazování, či obecněji svoji metodologii, ale také umožní pochopit povahou sociálních problémů, které z těchto rozdílů vyplývají (srov. Mills 1939: 675, 1940b: 329), a umožní dostat do zorného pole podle Millse dlouhodobě přehlížený proces sociální změny. Pro něj je podstatné především uplatnění mnohoúrovňového pohledu při zkoumání příčin sociálních problémů, které je zároveň nutnou podmínkou demokratické implementace sociální změny. Nezbytným předpokladem je pak samotná reflexivita úlohy sociální vědy, která může vést k detekování stávajících chyb a formování lepšího paradigmatu budoucího výzkumu (srov. Mills 1939: 675, 1940b: 329-330).

V.

Tyto texty naznačují, co se stalo pro sociologickou imaginaci typickým. Subjekt je nahrazován sociální situovaností či sociální strukturou. Imanence se proměňuje v transcendenci, empirické v pochybné a jakýkoli systém vědění či racionality je v tomto způsobu imaginace

4 Now the sociologist of knowledge is explicitly concerned with factual investigations of the verbal components of action, with the "common sense," e.g., articulations of various cultures. In this field one of his problems is the ascertaining of differential disparities obtaining between overt systems of behavior and what is said by the actors in different cultural contexts (Mills 1940b: 329). 
redukován na common sense, při jehož postižení se sociální vědec stává jeho absolutním měřítkem umožňujícím mu zaujmout pozici svrchovaného kritika.

Ve svém důsledku je však tento přístup podivný. Sociální struktury jsou mnohem reálnější než samotný aktér, který je pasován do nerozumného nevědoucího chyceného v osidlech mýtů a pověr.

Obyčejní lidé, zajatí v omezeném prostředí své každodennosti, často ani nepřemýšlejí o velkých strukturách, racionálních i iracionálních, jichž jsou jejich prostředí podřízenou součástí. Často pak uskutečňují řadu zdánlivě racionálních činností, aniž vědí, k jakým účelům slouží. (...) Jak se ukazuje, věda není nějaký technologický Poslední soud. To, že její techniky a racionalita získaly ve společnosti stěžejní místo, neznamená, že lidé žijí rozumně, bez mýtů, bludů a pověr. (Mills 2008: 182)

Sociální imaginace směřuje k osvojení si schopnosti odhlédnout od existujících mínění nabízejících způsoby zakoušení skutečnosti, včetně interpretačních schémat nereálného ve prospěch reálných sociálních struktur. V tomto smyslu by se podle Millse sociální vědec měl naučit ve jménu fakticity či pravdy, rozumu a lidské svobody identifikovat reálné problémy ve vztahu k sociologem koncipované sociální struktuře.

Co je míněno požadavkem, aby se naše výzkumy zaměřovaly na důležité nebo - jak je to často řečeno - významné problémy? (...) Zde je třeba říci, že tím nemyslím pouze to, že by měly mít politický, praktický nebo morální význam - at' už je smysl těchto pojmů jakýkoli. Je tím především míněno, že by měly mít skutečný význam pro naše pojetí sociální struktury a pro to, co se v ní děje. „Skutečný význam“ zde znamená, že naše výzkumy musí být logicky propojeny s těmito koncepcemi. (ibid.: 82)

Takto vytyčený program postuluje především problém vztahu mínění a skutečnosti. Tato pozice je však problematická, vyplývající z prvoplánového hodnocení praktik zdravého rozumu jako nereálných smyšlenek, které jsou produkčním efektem faktických sociálních struktur. Zatímco mínění je Millsem ztotožněno s mýty, bludy a pověrami, sociální struktura je jím přijímána jako fakt. Nicméně toto kanonické rozlišení mezi věděním a míněním je však paradoxní, stavící proti sobě podmíněnost a autonomii. Bud’ je něco nezávislé a nepodléhá konstrukčním efektům lidské činnosti, nebo naopak.

Tento postoj staví běžné aktéry do pozice naivních věřících, zatímco sociální badatele vyzbrojené sociální imaginací do role vlastníků pravdy a oprávněných vykladačů skutečnosti. Dějiny lidského myšlení jsou prodchnuty touto obrazoboreckou tendencí. Abrahámova vzpoura proti modlářství, byzantské obrazoborectví ve sporu o uctívání ikon či luteránské tažení proti mariánským zázrakům jsou zřejmě nejznámější z nich. Přes jejich odlišnost však mají jedno společné. Vždy dochází k rozlišení mezi faktickým a smyšleným. Zatímco mínění je koncipováno analogicky $\mathrm{k}$ víře jako naivní víra věřících, faktické je pojímáno jako reálné. Mínění má pouze subjektivní relevanci. Jde o sekundární kvality, které ve svém důsledku nemohou říci nic o tom, čím je svět, ve kterém tito „naivni““ žijí, ve skutečnosti tvořen. Jde o imaginární světy, které se jeví jako významonosné (významné) pouze ve vztahu k psychickým, emotivním nebo osobnostním postojům. Ve skutečnosti tak mínění nemají žádný 
ontologický status. Skutečná je pouze sociální struktura, která se promítá do různých forem reprezentací.

Co je vnímáno na úrovni zdravého rozumu jako autonomní, je na straně sociologů obdařených Millsovou sociologickou imaginací mýtem, bludem či pověrou, dnes bychom spíše řekli sociální nebo diskurzivní konstrukt. Autonomní je vždy sociální struktura. Potíž je v tom, že totéž lze říci i o fakticitě. Ta je konstrukčním efektem badatele. Pokud je fakt konstruován správně, je vyhodnocen jako autonomní, reálný a zároveň pravdivý. Pokud je však vyhodnocen špatně, je posuzován jako sociální produkt. Chybu v př́ípadě vědeckých faktů, stejně jako mínění, lze vysvětlit jako sociální produkt a objev faktu jako výsledek svobodné, ničím nepodmíněné vůle badatele (srov. Latour 1999: 273-274). Mínění či vědecké chyby, a tato tendence je u Millse zřejmá, vystupují jako sociální konstrukty a sociologický imaginátor je měřítkem těchto konstruktů. Stává se ničím a nikým nepodmíněným kritikem.

Tato pozice je však rozporuplná, stavící sociálního vědce proti samotné (př́írodní) vědě, jak bylo naznačeno $\mathrm{v}$ př́padě Kuhna. Zejména část feministické kritiky vytvořila program suspendující vědu na mocenský aparát reprezentující patriarchální rád. $V$ této perspektivě jsou vědecké objevy historickými událostmi činícími z vědy mocenský nástroj, pro který je typická akumulace ekonomické a politické moci. Je komplexem diskriminačních technik, které z vědy nečinní oblast nevinnosti, ale spíše zrcadlo společenských tendencí či důsledků existujících sociálních struktur (viz Harding 1986, 1991).

Takto transponovaný problém feminismu do vědy, jakkoli je v mnoha bodech oprávněný, zakládá předpoklad, $v$ němž se Millsem požadovaná sociologická imaginace proměňuje v paranoiu charakteristickou všeobecnou nedůvěrou ve vědu. Tyto diskuse mají vždy dva základní rysy. První z nich je, že diskuse je vystavěna tak, že objev či věda je charakterizována jako mocenský nástroj $\mathrm{k}$ dosažení ekonomického či politického profitu. Kritik se staví do pozice emancipátora těch, kteří podléhají těmto mocenským důsledkům a nejsou si jich vědomi, a samožrejmě jedině on - kritik si je jich vědom a není jimi podmíněn, ani svojí kritikou nesleduje žádné druhy profitu, protože mluví ve jménu pravdy, svobody a rozumu (srov. Denzinovu kritiku Millse). Pokud však je vůči kritikovi použit stejný argument, totiž že je jeho kritika stejnou mocenskou strategií jako každá jiná, nebo se ukáže, že je chybná či zavádějící, uchyluje se ke strategii rovnosti interpretací, v níž by jeho vysvětlení mělo být respektováno, stejně jako respektuje on jiná vysvětlení, protože jde o jeho názor a on má na svůj názor v kontextu svobody slova stejné právo jako kdokoli jiný. Tato kritika je sice neprůstřelná, staví však všechny proti všem.

Podobnou nedůvěru zasévají sociální vědci vůči samotné sociální vědě. V sociální imaginaci rozvíjejí přístup teorie superega, v níž individuální životy, včetně jejich psychických prožitků, jsou projevem sociální struktury či obecněji jakéhokoli nadindividuálního celku, jehož důsledku si nejsou dotyčná individua vědoma. Sociální věda je tak vědou falešného vědomí, či dokonce nevědomí a sociální vědec své poznání buduje jako emancipační techniku. Výsledkem je kritika, která však staví sociální vědu proti Millsovu obyčejnému člověku. Sociologické vědění v rukou takového sociálního kritika se stává disciplinačním nástrojem, který je vždy použit, pokud je myšlení nebo jednání konkrétního jednotlivce či skupin vyhodnocováno jako stereotypní akt, který je v rozporu s aktuálním sociálním věděním. Je to novodobý druh flagelantství vyžadující pokoru nebo podřizení se 
sociálněvědnímu pokrokovému vědění, které podle mne hrozí rizikem zpochybnění společenské potřebnosti vědy.

$\mathrm{K}$ této možná poněkud přehnané pesimistické vizi mne vede analogie s nedůvěrou $\mathrm{v}$ katolickou církev, která kulminovala ve Francii během Francouzské revoluce. Ještě před nástupem reformace byla katolická církev integrální součástí života běžných lidí. Pod vlivem reformace, umocněným následnou koloniální zkušeností, však začala přistupovat $\mathrm{k}$ běžným lidem s odstupem. Věřící začali být nahlíženi jako pověrčivá masa ignorantů, kteří jsou náchylní k herezi. Kněz rozuměl sobě jako misionárii, jehož posláním bylo vyhlásit válku všem lidovým zvykům a přesvědčením odporujícím principům pravé víry a morálky. $\mathrm{K}$ francouzskému lidu přistupoval spiše jako k indiánům, orientálcům či novodobým pohanům než ke svým souvěrcům. Křest’anská kolegialita byla vystř́ídána všudypř́tomnou disciplinací, která se během francouzské revoluce obrátila proti katolické církvi (srov. Bell 2001: 85-86).

Ukazuje se, že pod vlivem takového obrazoborectví jsou unaveni všichni. Všichni se osočují ze lži. Politika pravdy stvořila kulturu lži, v níž každý je považovaný za trolla. Politika osvícenství staví všechny do pozice osvícených elit, které selhaly tím, že svůj ideál nadřazují nad reálné problémy obyčejných lidí a pasují se do role jejich mluvčí. Co takhle zapomenout na obyčejného člověka, který je výrazem průměru čehokoli a v němž je přehližžena jeho jedinečnost, která by měla být vysvětlena, nikoli přehlížena? Co takhle zapomenout na elitáře, kteří koncipují Millsova člověka jako důsledek masy vyjadřující společnou vůli, v níž se elitář či samozvaný leader stylizuje do jejího tlumočníka (srov. Eco 1995)? Co takhle zapomenout na sociologickou imaginaci sociálního transcendentna?

\section{Závěr}

Vzdát se takové sociologické imaginace znamená především vzdát se generálního předsudku činícího rozdíl mezi strukturou a subjektem. Struktury zde vystupují jako vnější sféra, která se stává absolutním měřítkem myslícího a jednajícího subjektu. Zdrojů tohoto předsudku je hned několik. První vyplývá z nekriticky aplikovaného pojetí prostoru, který je koncipován jako kontejner, do kterého je situováno vše existující (srov. Latour 1999: 1-23; Mol, Law 1994). Tento aspekt se promítá i do prvoplánového dělení skutečnosti na prírodu a společnost, $v$ němž př́roda a společnost vystupují jako všeobjímající, metafyzické sféry, které se odlišují jen v primárnosti transcendence. Př́rodní struktury jsou charakteristické zákonitostmi, které jsou nezávislé na člověku, zatímco sociální struktury jsou koncipovány jako výsledek lidské činnosti. Toto rozlišení trvá jen do okamžiku, kdy se začneme ptát, jak jsou tyto odlišné struktury zkoumány. Př́rodní struktura je objevována v kontextu vědeckých technik a je tedy výsledkem lidské činnosti, zatímco sociální struktura je ve výzkumu koncipována jako autonomní, na člověku nezávislá transcendentní oblast podmiňující jednání členů konkrétní společnosti (srov. Latour 2003:48-51). Zejména tendence zkoumat společnost či sociální strukturu jako transcendentní sféru se odráží v záměně tří vědeckých požadavků, kolem kterých se formuje Millsem koncipovaná sociologická imaginace.

První aspiruje na evidenci způsobů utváření společnosti související s činností a vynalézavostí jejích členů. Druhý se snaží uspořádat kontroverze o tom, čím je společnost tvořena, omezením širokého spektra entit činných v sociálním světě. Poslední se snaží nabídnout řešení sociálního problému politickou akcí. Tyto požadavky sociální vědy jsou 
oprávněné (srov. Latour 2005: 160), prostor sociologického imaginária se však začne objevovat v momentě, kdy dochází $\mathrm{k}$ záměně těchto požadavků tak, jak to učinil Mills ve svých raných textech, které se mu staly odrazovým můstkem k vypracování vlastního konceptu sociologické imaginace jako východiska k řešení závažných sociálních problémů.

Pokud dojde k záměně druhého za první, sociolog se začne domnívat, že musí omezit rozsah nejistot či kontroverzí, protože jsou předpokládány jako zdroj sociálních problémů. Konkrétní aktéři s jejich konkrétními strategiemi utváření společnosti se ztrácejí a aktérství se v této redukci přiznává sociologem preferované entitě (struktuře, genderu, diskurzu) a z aktivních aktérů činí pasivní produkty těchto sociologických entit. Ze sociologie se tak stává svérázná vědní disciplína, jejímž nezbytný předpokladem je schopnost imaginace těchto redukovaných, vždy transcendujících entit (srov. ibid.: 160).

Pokud zaměníme třetí s druhým, dojde k záměně aktérského utváření sociálního s vlastní definicí toho, co sociální tvoří a co ho drží pohromadě. Kontroverze kolem sociálního jsou vyhodnoceny jako závažný sociální problém, spojený především s otázkou, co je společnost a kam směřuje, a jeho řešení vyžaduje politické řešení, které má respektovat imaginující sociologické vědění budované na znalosti reálného podmínění sociálních vztahů. Výsledkem těchto záměn je, že sociálno jako předmět sociologie se stalo nedostupným navzdory tomu, že sociologická vysvětlení skrze sociologickou imaginaci neustále proliferují (srov. ibid.: 161).

Takto rozvíjená sociální imaginace jde ve svém důsledku proti weberovskému principu odkouzlení světa. Ve snaze postihnout vymezené úkoly svět člověka odděluje od přírody a ve své specifické imaginaci ho zaplňuje stále novými metafyzickými entitami, jimž se musí člověk ve jménu celku podřídit, nebo naopak musí být na nich emancipován. Ty tvoří kontext konkrétního jednání či myšlení, jsou jeho horizontem, bez ohledu na to, že ve svém důsledku bezbřehým, zato vždy strukturovaným.

Přechod mezi těmito individualizovanými činy myšlení či jednání a nadindividuálními metafyzickými kontexty hrozí rizikem přisouzení jedné z těchto oblastí statusu aktivity, druhé pak pasivity, inklinující k nekonečným debatám o primárnosti struktur či jednání, a jakákoli analýza je potom pouze demonstrací těchto vysoce abstrahovaných entit. V této abstrakci nejde jednoduše o struktury, ale také o individuální schéma jednání či myšlení. Každá imaginace struktury dříve nebo později vede k představám konkrétní pragmatiky. Potom však nelze opomenout, že abstrakcí není jen struktura, ale také sama interakce (srov. ibid.: 167-168). Východiskem z této svízele však není jednoduše něco vztahovat ke kontextu. Takové řešení je vedeno a podmíněno sociologickou imaginací, charakteristickou neustálým oddělováním sociálního od přírodního, struktury od jednání, vrcholící vždy stanovením rozdílu mezi reálným a nereálným, v němž se sociologický imaginátor pasuje na vlastníka absolutní pravdy.

\section{Literatura}

BALON, Jan. 2009. „Ambivalentní odkaz Millsovy Sociologické imaginace.“ Sociologický časopis/ Czech Sociological Review 45(5): 1055-1072.

BECK, Ulrich. 2007. „The Cosmopolitan Condition: Why Methodological Nationalism Fails.“ Theory, Culture \& Society 24(7-8): 286-90. 
BELL, David. 2001. „Culture and Religion.“ Pp. 78-104 in W. DOYLE (ed.). Old Regime France, 1648-1788. Oxford: Oxford University Press.

BINNS, David. 1977. Beyond the Sociology of Conflict. London: Macmillan.

BOURDIEU, Pierre. 2003. „Participant Objectivation.“ Journal of the Royal Anthropological Institute 9(2): 281-94.

BROWNE, Ken. 2011. An Introduction to Sociology. Cambridge: Polity.

BURAWOY, Michael. 2005. „2004 ASA Presidential Address: For Public Sociology““ American Sociological Review 70(1): 4-28.

BURAWOY, Michael. 2008. „Open Letter to C. Wright Mills.“ Antipode 40(3): 365-75.

DALY, Mary. 2005. „Gender Mainstreaming in Theory and Practice.“ Social Politics: International Studies in Gender, State \& Society 12(3): 433-50.

DENZIN, Norman K. 1989. „Re-Reading the Sociological Imagination.“ The American Sociologist 20(3): 278-82.

DENZIN, Norman K. 1990. „Presidential Address On The Sociological Imagination Revisited.“ The Sociological Quarterly 31(1): 1-22.

ECO, Umberto. 1995. „Ur-Fascism.“ The New York Review of Books. Cit. 9. 5. 2018 (http://www. nybooks.com/articles/1995/06/22/ur-fascism/).

FERRANTE, Joan. 2010. Seeing Sociology: An Introduction. Belmont: Wadsworth.

FERRIS, Kerry a Jill STEIN. 2009. The Real World: An Introduction to Sociology. New York: W.W. Norton \& Company.

FEYERABEND, Paul. 1993. Against Method. London: Verso.

FOWLER, Roger. 1996. „On Critical Linguistics.“ Pp. 3-14 in Carmen Rosa CALDAS-COULTHARD a Malcolm COULTHARD (eds.). Texts and Practices: Reading in Critical Discourse Analysis. London: Routledge.

GIACOMINI, Mita. 2004. „Interdisciplinarity in Health Service Research: Dreams and Nightmares, Maladies and Remedies." Journal of Health Services Research \& Policy 9(3): 177-183.

GIDDENS, Anthony. 2013. Sociologie. Praha: Argo.

GOULDNER, A. Ward. 1971. The Coming Crisis of Western Sociology. New York: Basic Books.

GOULDNER, A. Ward. 1973. For Sociology: Renewal and Critique in Sociology Today. New York: Basic Books.

GROSS, Neil. 2007. „Pragmatism, Phenomenology, and Twentieth-Century American Sociology.“ Pp. 183-224 in Craig CALHOUN (ed.). Sociology in America. A History. Chicago: The University of Chicago Press.

HACKING, Ian. 1999. The Social Construction of What? Cambridge, MA: Harvard University Press.

HAMPLOVÁ, Dana. 2011. „Náboženství a pohlaví: Proč jsou ženy zbožnější než muži?“ Sociologický časopis 47(2): 297-323.

HARDING, Sandra. 1986. The Science Question in Feminism. Ithaca: Cornell University Press.

HARDING, Sandra. 1991. Whose Science? Whose Knowledge?: Thinking from Women's Lives. Ithaca: Cornell University Press.

HANISCH, Carol, Caty SCARBROUGH, Ti-Grace ATKINSON a Kathie SARACHILD. 2013. „Forbidden Discourse: The Silencing of Feminist Criticism of Gender.“ Cit. 25. 5. 2018 (https://feministuk. wordpress.com/2013/08/19/forbidden-discourse-the-silencing-of-feminist-criticism-of-gender/).

HARVEY, Lee. 1982. „The Use and Abuse of Kuhnian Paradigm in Sociology of Knowledge.“ Sociology 16(1): 85-101.

JASANOFF, Sheila. 2012. „Genealogies of STS.“ Social Studies of Science 42(3): 435-441.

KATZ, Cindi. 2001. „Response: Disciplining Interdisciplinarity.“ Feminist Studies 27(2): 519-25.

KELLER, F. Evelyn, F. 1995. Reflections On Gender and Science. New Haven: Yale University Press.

KUHN, Thomas. 1970. The Structure of Scientific Revolution. Chicago: The University of Chicago Press. 
KUHN, Thomas. 1997. Struktura védeckých revolucí. Praha: OIKOYMENH.

KUHN, Thomas. 1970. „Reflections on my Critics.“Pp. 231-278 in Imre LAKATOS a Alan MUSGRAVE (eds.). Criticism and the Growth of Knowledge. Cambridge: Cambridge University Press.

LATOUR, Bruno. 1999. Pandora's Hope: Essays on the Reality of Science Studies. Cambridge, MA: Harvard University Press.

LATOUR, Bruno. 2002. „The Promises of Constructivism.“ Pp. 27-46 in Dod IHDE a Evans SELINGER (eds.). Chasing Technology. Matrix of Materiality. Bloomington: Indiana University Press.

LATOUR, Bruno. 2003. Nikdy sme neboli moderní. Bratislava: Kaligram.

LATOUR, Bruno. 2005. Reassembling the Social: An Introduction to Actor-Network-Theory. Oxford: Oxford University Press.

LUŽNÝ, Dušan. 2014. „Kulturní pamět’ jako koncept sociálních věd.“ Studia philosophica 61(2): 3-18.

LUŽNÝ, Dušan a Jan VÁNĚ. 2017. „Koncept kolektivní paměti - základní východiska a závěry.“ Historický časopis 65(4): 577-590.

LYND, Robert S. 1970 (pův. vyd. 1939). Knowledge for What?: The Place of Social Science in American Culture. Princeton: Princeton University Press.

MARTINS, Herminio 1972. „The Kuhnian Revolution and Its Implications for Sociology.“ Pp. 13-58 in Thomas J. NOSSITER, Albert H. HANSON a Stein ROKKAN (eds.). Imagination and Precision in the Social Sciences: Essays in Memory of Peter Nettl. London: Faber \& Faber.

MILLS, Charles Wright. 1939. „Language, Logic and Culture.“ American Sociological Review 4 (5): 670-680.

MILLS, Charles Wright. 1940a. „Situated Actions and Vocabularies of Motive.“ American Sociological Review 5(6): 904-913.

MILLS, Charles Wright. 1940b. „Methodological Consequences of the Sociology of Knowledge.“ American Journal of Sociology 46(3): 316-330.

MILLS, Charles Wright. 1948. The New Men of Power: America's Labor Leaders. Champaign: University of Illinois Press.

MILLS, C. Wright. 1951. White Collar: The American Middle Classes. Oxford: Oxford University Press.

MILLS, Charles Wright. 1959. The Sociological Imagination. Oxford: Oxford University Press.

MILLS, Charles Wright. 1966. Mocenská elita. Praha: Orbis.

MILLS, Charles Wright. 2008. Sociologická imaginace. Praha: Sociologické nakladatelství.

MOL, Anmemarie a John LAW. 1994. „Regions, Networks and Fluids: Anaemia and Social Topology.“ Social Studies of Science 24(4): 641-71.

PERDUE, Katharine. 2003. „Imagination.“ Cit. 7. 1. 2019 (http://csmt.uchicago.edu/glossary2004/ imagination.htm).

ROSENBERG, Justin. 1994. „The International Imagination: IR Theory and ,Classic Social Analysis.““ Millennium: Journal of International Studies 23(1): 85-108.

SEIDMAN, Steven. 2013. Contested Knowledge: Social Theory Today. Hoboken: John Wiley \& Sons.

SUNDERLIN, William D. 2003. Ideology, Social Theory, and the Environment. Lanham: Rowman and Littlefield.

ŠOTOLA, Jaroslav. 2018. „Gender je i pro křest’any.“ Cit. 7. 1. 2019 (http://www.christnet.eu/clanky/ 6159/gender_je_i_pro_krestany.url).

TISCHLER, Henry. 2006. Introduction to Sociology. Belmont: Wadsworth Publishing.

URRY, John. 1973. „Thomas Kuhn as Sociologist of Knowledge.“ The British Journal of Sociology 24(4): 462-473. 


\section{Autor}

Tomáš Kobes je sociální antropolog. Působí jako odborný asistent na Katedře sociologie, FF ZČU v Plzni. Ve svých výzkumech se zaměřuje na př́ibuzenství východoslovenského venkova, zavádění základní infrastruktury do areálů romských osad či formování kolektivní paměti ve vztahu k materiálním objektům a infrastruktuře. Tato terénní zkušenost přispěla i k formování jeho teoretické specializace pohybující se $\mathrm{v}$ oblastech nových př́ibuzenských studií, kritické diskurzivní analýzy, teorie aktérů-sítí a ontologického obratu v sociální vědě. Kontakt: kobes@kss.zcu.cz 